ON THE RECORD

cOld octopuses

become what we call

senescent, or senile...

and sometimes their

actions are very

inappropriate."

Jim Cosgrove of the Royal British

Columbia Museum speculates about why an octopus recently attacked a

small research submarine.

(CPlease note that from

now on, Orion's Belt

will be replaced by

Chantelle's Thong."

Columnist Lucy Mangan derides

the decision to replace London

Planetarium programmes with

a show about celebrities.

cYou cannot ethically... infect humans and see

if they get fat."

Leah Whigham of the University of Wisconsin, Madison, explains why she infected chickens, not people, with a virus linked to obesity.

Sources: CBC, The Guardian, The Telegraph

\section{SCORECARD}

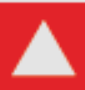

Moon mining

Russia'sstate-owned space company says that

the nation plans toestablish a

Moon base and mine lunar helium-

3 as a fuel for fusion reactors.

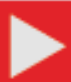

Placebos

Sham acupuncture works better than a cornstarch

pill at easing arm pain, says a comparison published in the BMU.

Telegrams

After 150 years, Western

Union hassent itslast

telegram. The compary, which

alsodoes money orders, saysit

willnow focus on "financial

services".

\section{OVERHYPED}

\section{Bird flu in Aus tria}

Panic spread throughout Vienna last week after citizens reported some 40 dead songbirds.

Autopsies showed that the H5N1 flu virus was not to blame. The larks, it seems, had developed an ap petite for fermented berries, and got so drunk that they flew into windows.

\section{One place, one parent, two species}

Evolutionists have provided what they hope is a definitive answer to the question of whether 'sympatric speciation' can occur in the natural world. This is where two or more species diverge from a common ancestor despite sharing the same habitat. The process has been taught as part of evolutionary theory for decades, but has been notoriously difficult to prove.

There are candidate cases, such as where parasitic species seem to have diverged on the same host. But solid examples are hard to pin down, as they require showing that two or more species descended from a single ancestor, and that the lineages did not spend any time apart during the entire course of their divergence - often a span of several million years.

Two studies in disparate parts of the globe offer what their authors say are the best shots so far at such a proof. On page 719 of this issue, Axel Meyer and colleagues at the University of Konstanz in Germany describe two fish species that have apparently diverged despite sharing a relatively small lake (5 kilometres across) in Nicaragua. According to Meyer and his team, it's next to impossible that two such dosely related species could have ended up in this very young (less than 23,000 -year-old),

\section{IMAGE UNAVAILABLE FOR COPYRIGHT REASONS}

Evidence found: two species of palm on an island in Australia seem to have diverged side by side.

isolated lake through two colonization events.

In a second study, Vincent Savolainen of Britain's Royal Botanic Gardens in Kew and his colleagues report that two species of palm tree seem to have diverged on a remote Australian island (V. Savolainen et al. Nature doi:10.1038/ nature04566; 2006). In this case, the remoteness of the island and the shared genetic traits of the species make it extremely unlikely that the trees are descendants of two ancestors that arrived at the island on separate occasions.

"Almost no proposed example of sympatric

\title{
Political strife set to delay EU funds
}

\section{MUNICH}

A power struggle between the European Parliament and member states of the European Union (EU) threatens to delay the start date of the EU's next funding programme for research - and that of its new flagship funding agency, the European Research Council (ERC).

In December, the EU's 25 heads of government agreed a total budget for $2007-13$, including a $75 \%$ increase in research spending by 2013 . If the money rises steadily over that period, the budget for the seventh EU Research Framework Programme (FP7) will be roughly $€ 50$ billion (US $\$ 60$ billion). That's $€ 20$ billion less than originally proposed by the European Commission, which aimed to double research spending by 2013.

A research-friendly majority in the European Parliament had also hoped for more. On 18 January, the parliament rejected the proposed EU budget by 541 votes to 56 , forcing governments to renegotiate. "We don't reject the budget lock, stock and barrel," says Jorgo Chatzimarkakis, a liberal democrat MEP from Germany. "But we can't accept cuts in research that are disproportionately larger than in agriculture and structural funds."

Although the possibility of an extra few billion euros for research may please 


\section{IMAGE UNAVAILABLE FOR COPYRIGHT REASONS}

speciation can be considered absolutely beyond doubt," comments Jerry Coyne, an evolutionary biologist at the University of Chicago, Illinois. But in both of the newly reported cases, he says, sympatric speciation seems the most likely explanation. William Baker, part of the Kew team, agrees: ${ }^{\alpha} \mathrm{My}$ first reaction is that it's hard to imagine a case being neater than ours - it sounds immodest but it's almost the ideal scenario."

The big question now is whether sympatric speciation is widespread or rare. Although it is relatively easy to make a convincing case for a remote island or small isolated lake, things will be much tougher when biologists turn to more complex ecosystems such as East Africa's great lakes, home to hundreds of related fish species. "What would overturn our view of evolution would be to find that a fairly substantial proportion of all speciation events occur in sympatry," Coyne says.

The concept that such speciation is widespread was largely resisted by the great evolutionist Ernst Mayr, who died last year, says Meyer. Such was Mayr's influence among biologists that he engendered a widespread bias against the idea. "But I think sympatric speciation will turn out to be more common than people thought," Meyer adds.

Michael Hopkin
Europe's science community, research managers fear continued political wrangling will lead to delays. Governments are unlikely to substantially revise the overall budget, which they agreed, after prolonged negotiations, just before the British EU presidency ended. So it is up to the commission to deliver a revised proposal for FP7. But insiders say departments are fighting over how to cope with the reduced budget.

"The calendar for the adoption of FP7 is now extremely tight," Janez Potočnik, the EU's research commissioner, told a parliament committee on 26 January. "If we are to deliver a Framework programme in time for 2007 ... we must ensure that there are no delays on either side."
The commission had earmarked $€ 1.5$ billion per year for the ERC, which will fund basic research, but that figure is now unlikely. " $€ 1$ billion per year is the absolute minimum required for the ERC to make sense," says Carl-Henrik "We're anxious to get

Heldin, director of the Ludwig Institute of Cancer Research in Uppsala, Sweden. "We're anxious to get started in January, and get the first money paid out by the end of 2007."

Peter Dröll, head of Potočnik's staff, says FP7 could make its schedule, provided the EU budget is approved by April. But that's far from certain. 'I reckon we'll need at least until the summer break," says Angelika Niebler, a Christian democrat MEP who acts as rapporteur for the ERC.

Quirin Schiermeier 